\title{
Breast Cancer Prevention Information Seeking Behavior and Interest on Cell Phone and Text Use: a Cross-sectional Study in Malaysia
}

\author{
Mehrnoosh Akhtari-Zavare ${ }^{1}$, Abbas Ghanbari-Baghestan ${ }^{2 *}$, Latiffah A Latiff ${ }^{3}$, \\ Hadi Khaniki ${ }^{4}$
}

\begin{abstract}
Background: Breast cancer is the most common cancer and the second principal cause of cancer deaths among women worldwide, including Malaysia. This study focused on media choice and attempted to determine the communication channels mostly used and preferred by women in seeking information and knowledge about breast cancer. Materials and Methods: A cross sectional study was carried out to examine the breast cancer prevention information seeking behavior among 450 students at one private university in Malaysia. Results: The mean age of respondents was $25 \pm 4.3$ years. Common interpersonal information sources were doctors, friends, and nurses and common channel information sources were television, brochure, and internet. Overall, 89.9\% used cell phones, $46.1 \%$ had an interest in receiving cell phone breast cancer prevention messages, $73.9 \%$ used text messaging, and $36.7 \%$ had an interest in receiving text breast cancer prevention messages. Bivariate analysis revealed significant differences among age, eduation, nationality and use of cell phones. Conclusions: Assessment of health information seeking behavior is important for community health educators to target populations for program development.
\end{abstract}

Keywords: Breast cancer - health information - communication channels - media choice - Malaysia

Asian Pac J Cancer Prev, 16 (4), 1337-1341

\section{Introduction}

Breast cancer appears to be a major global health problem of both the developing and developed countries (World Health Organization, 2009). Similarly, in Malaysia, breast cancer is the most common cancer among women and it comprises $31 \%$ of all female cancers (Yip et al., 2011).

Few studies suggest low breast cancer knowledge among college women (Early et al., 2011; Andsoy et al., 2014). The findings emphasis the important need for breast cancer prevention information for young women. Increased knowledge may influence perceived higher susceptibility to breast cancer and behavior changes (Early et al., 2011; Andsoy et al., 2014). Women during college years may adopt healthy lifestyles for cancer risk reduction and age-appropriate screenings (American Cancer Society., 2013).

One of the way for providing breast cancer prevention information is using communication chennels, especially new media channels, as sources of health information(Kelly et al., 2009). In other words, health information sources are the communication channels which carry knowledge and information that include interpersonal media, mass media,promotional media and new media and technologies. Interpersonal channels such ashealth providers, family, or friends which all related to face to face communication. Mass media channels may include television, magazines, newspapers and radio. Promotional media may include brochures and flyers and new media and technologies may include the internet based channels such as websites, blogs, social media and etc (GhanbariBaghestan et al., 2009; Kratzke et al., 2014).

Although face to face communication are still likely to be an important channel, with the growth of new communication technology, it is no longer the sole communication medium used by women for health information. Studies show the Internet is becoming a preferred channel source since it offers a wealth of information for consumers and cancer survivors (Longo et al., 2009; Kelly et al., 2009). According to Pew Internet and the American Life Project research (2013), $72 \%$ of adults ages 18-29 actively seek online health information compared to $54 \%$ of adults ages 50-64. In one study, findings show family/friends (90\%) and the Internet (79\%) were the most frequent breast cancer prevention information sources among female staff of University of Malaya, Malaysia (Dahlui et al., 2011). In contrast, in

${ }^{I}$ Cancer Resource and Education Center, ${ }^{3}$ Department of Community Health, Faculty of Medicine and Health Science, Universiti Putra Malaysia, Serdang, Selangor, Malaysia, ${ }^{2}$ Department of Communication, Faculty of Social Science, University of Tehran, ${ }^{4}$ Department of Communication, Faculty of Social Science, Allameh Tabataba'i University, Tehran, Iran *For correspondence: Ghanbari.abbas@ut.ac.ir 
study conducted among 321 Turkish residential women, showed that health providers were the major source of information on breast cancer prevention $(48.3 \%)$, followed by media (39.2\%) and internet (12.5\%) (Yilmaz et al., 2013).

A newer communication channel is the use of cell phones with texting. Cell phones are being more and more frequently used for teaching and learning purposes in Asian countries (Motlik, 2008). It has been associated with age, income, work status and marital status (Rice et al., 2003). Text messaging expands into healthcare as a health communication tool for patient health prevention information source, reminders, motivation, and support. Text messaging shows promise in previous studies as a health information source in interventions (Fukuoka et al., 2011). According to Pew Internet and American Life Project (2012) the majority of young adults ages 18-29 own smartphones $(66 \%)$ and $42 \%$ seek online health information using cell phones.

In Malaysia, few published studies have explored the use of cell phones and internet for providing breast cancer prevention information for young women. Consequently, the purpose of this study was to examine prevention information seeking behaviors among collage women, the prevalence of Internet, cell, and text use, and interest for breast cancer prevention information cell or text messages.

\section{Materials and Methods}

\section{Research design}

A cross sectional study was conducted from November 2012 to March 2013 among 450 students at two private universities in Malaysia. Respondents were identified and selected using simple random sampling from the list of students who registered.

\section{Questionnaire}

A 26-item paper and pencil bilingual survey was developed for data collection. The Malay version of questionnaire was developed with back translation by two language experts. The self-administered survey included four sections with items for breast cancer prevention information sources, channel sources, mobile technology, and demographics. The questionnaire was pre-tested among 30 students for checking the clarity of the items. Participants were able to respond with possible multiple answers. Interpersonal communication sources included 8 items such as doctors, family, or clinic staff members and mass media sources included 8 items such as newspaper, radio, or television. Items for mobile use and mobile message preferences included use of cell phones or text messaging (Yes/No) and interest in receiving breast cancer prevention information cell phone or text message (Yes/ No). For women with no interest to receive cell or text prevention Messages, open-ended items such as "If no, why not?" were used to elicit barriers for technology use. Demographics included age, marital status, nationality, level of education and income.

Data analysis

Data was analyzed by using PASW Statistics 20.0 program. Descriptive statistics and frequency distributions were analyzed for variables. Pearson Chi-Square was used to test for association between cell phone and text messaging use and demographics (marital status, and nationality, level of education) and for continuous variables (age and income) independent sample t-test was used. The level of statistical significance was test at $\alpha \leq 0.05$.

\section{Results}

\section{Response rate}

A total of 450 respondents were selected as the sample of the study. However, 25 respondents $(5.5 \%)$ refused to participate, and hence, 425 students filled up questionnaire. The response rate derived in this study was $94.4 \%$.

\section{Demographics and characteristics of respondents}

Table 1 shows the demographic characteristics of participants. The ages ranged from 20 to 36 with the mean age of $25 \pm 4.0$. The majority of participants were single $(76.2 \%)$, had bachelor degree $(48.2 \%)$, with the mean of family incomes $10636.47 \pm 2418.03$ and from Southeast Asia $(49.4 \%)$. Of the 382 cell phone users, $46.1 \%$ had an interest to receive a cell phone prevention message. Of the 314 text users, $36.7 \%$ had an interest to receive a breast cancer prevention text message.

\section{Interpersonal and channel sources}

Result of interpersonal sources show that, doctor was the main interpersonal sources 137(32.2\%). Friends 92 $(21.6 \%)$, nurses $79(18.6 \%)$, family $65(15.3 \%)$, others $29(6.8 \%)$ and co-workers $23(5.4 \%)$ were mentioned as other interpersonal sources. The channel sources included television $163(38.4 \%)$, brochure 95(22.4\%), internet

Table 1. Demographics and Characteristics $(n=425)$

\begin{tabular}{|c|c|c|c|}
\hline \multicolumn{2}{|c|}{ Demographics \& characteristics } & \multicolumn{2}{|c|}{ Total } \\
\hline & & $\mathrm{n}$ & $\%$ \\
\hline Age & $($ mean $\pm S D)$ & $25 \pm 4$ & \\
\hline \multirow[t]{2}{*}{ Marital status } & Married & 101 & 23.8 \\
\hline & Single & 324 & 76.2 \\
\hline \multirow[t]{3}{*}{ Education } & Bachelor & 205 & 48.2 \\
\hline & Master & 190 & 44.7 \\
\hline & $\mathrm{Ph} . \mathrm{D}$ & 30 & 7.1 \\
\hline \multirow[t]{4}{*}{ Nationality } & Middle East & 96 & 22.6 \\
\hline & Southeast Asia & 210 & 49.4 \\
\hline & Center Asia & 51 & 12 \\
\hline & North Africa & 68 & 16 \\
\hline Income $(\mathrm{RM}) *$ & $($ mean $\pm \mathrm{SD})$ & \multicolumn{2}{|c|}{$10636.47 \pm 2418.03$} \\
\hline \multirow{2}{*}{ Use cell phone } & Yes & 382 & 89.9 \\
\hline & No & 43 & 10.1 \\
\hline \multirow[t]{2}{*}{ Use text messaging } & Yes & 314 & 73.9 \\
\hline & No & 111 & 26.1 \\
\hline \multicolumn{4}{|c|}{ Prefer cell phone prevention message } \\
\hline & Yes & 196 & 46.1 \\
\hline & No & 229 & 53.9 \\
\hline \multicolumn{4}{|c|}{ Prefer text prevention message } \\
\hline & Yes & 156 & 36.7 \\
\hline & No & 269 & 63.3 \\
\hline
\end{tabular}

*USD 1= RM 3.05 
Table 2. Cell Phone use and Interest for Receiving Cell Phone Messages

\begin{tabular}{|c|c|c|c|c|c|c|c|c|}
\hline \multirow[t]{3}{*}{ Demographics } & \multicolumn{4}{|c|}{ Use cell phone $(n=425)$} & \multicolumn{4}{|c|}{ Prefer breast cancer cell phone message $(\mathrm{n}=382)$} \\
\hline & \multicolumn{2}{|c|}{ Yes } & \multicolumn{2}{|c|}{ No } & \multicolumn{2}{|c|}{ Yes } & \multicolumn{2}{|c|}{ No } \\
\hline & $\mathrm{n}$ & $\%$ & $\mathrm{n}$ & $\%$ & $\mathrm{n}$ & $\%$ & $\mathrm{n}$ & $\%$ \\
\hline \multicolumn{9}{|l|}{ Age } \\
\hline$($ mean $\pm S D)$ & \multicolumn{2}{|c|}{$25 \pm 4$} & \multicolumn{2}{|c|}{$28 \pm 4 * * *$} & \multicolumn{2}{|c|}{$25 \pm 4.3$} & \multicolumn{2}{|c|}{$25 \pm 3.9$} \\
\hline \multicolumn{9}{|l|}{ Marital status } \\
\hline Married & 89 & 88.1 & 12 & 11.9 & 51 & 57.3 & 38 & 42.7 \\
\hline Single & 293 & 90.4 & 31 & 9.6 & 145 & 49.5 & 148 & 50.5 \\
\hline \multicolumn{9}{|l|}{ Education } \\
\hline Bachelor & 193 & 94.1 & 12 & $5.9 *$ & 95 & 49.2 & 98 & 50.847 .3 \\
\hline Master & 167 & 87.9 & 23 & 12.1 & 88 & 52.7 & 79 & 40.9 \\
\hline $\mathrm{PhD}$ & 22 & 73.3 & 8 & 26.7 & 13 & 59.1 & 9 & \\
\hline \multicolumn{9}{|l|}{ Nationality } \\
\hline Middle East & 91 & 94.8 & 5 & $5.2 * *$ & 34 & 37.4 & 57 & $62.6^{\bullet}$ \\
\hline Southeast Asia & 194 & 92.4 & 16 & 7.6 & 99 & 51 & 95 & 49 \\
\hline Center Asia & 40 & 78.4 & 11 & 21.6 & 25 & 62.5 & 15 & 37.5 \\
\hline North African & 57 & 83.8 & 11 & 16.2 & 38 & 66.7 & 19 & 33.3 \\
\hline \multicolumn{9}{|l|}{ Income } \\
\hline$(\operatorname{mean} \pm \mathrm{SD})$ & 1069 & 461.95 & 1009 & 1924.94 & 1070 & 469.12 & 1069 & 461.01 \\
\hline
\end{tabular}

$* \mathrm{p}<0.001$ for $\mathrm{x}^{2}$-tests; $* * \mathrm{p}<0.003$ for $\mathrm{x}^{2}$-tests; $* * * \mathrm{p}<0.000$ for $\mathrm{t}$-test; $\bullet \mathrm{p}<0.002$ for $\mathrm{x}^{2}$-tests

Table 3. Text use and Interest for Receiving Text Massage

\begin{tabular}{|c|c|c|c|c|c|c|c|c|}
\hline \multirow[t]{3}{*}{ Demographics } & \multicolumn{4}{|c|}{ Use texting $(n=425)$} & \multicolumn{4}{|c|}{ Prefer breast cancer text massage message $(\mathrm{n}=314)$} \\
\hline & \multicolumn{2}{|c|}{ Yes } & \multicolumn{2}{|c|}{ No } & \multicolumn{2}{|c|}{ Yes } & \multicolumn{2}{|c|}{ No } \\
\hline & $\mathrm{n}$ & $\%$ & $\mathrm{n}$ & $\%$ & $\mathrm{n}$ & $\%$ & $\mathrm{n}$ & $\%$ \\
\hline \multicolumn{9}{|l|}{ Age } \\
\hline$($ mean \pm SD) & \multicolumn{2}{|c|}{$25 \pm 2.4$} & \multicolumn{2}{|c|}{$26 \pm 4.5$} & \multicolumn{2}{|c|}{$26 \pm 4.3$} & \multicolumn{2}{|c|}{$25 \pm 4.0$} \\
\hline \multicolumn{9}{|l|}{ Marital status } \\
\hline Married & 82 & 81.2 & 19 & 18.8 & 44 & 53.7 & 38 & 46.3 \\
\hline Single & 232 & 71.6 & 92 & 28.4 & 112 & 48.3 & 120 & 51.7 \\
\hline \multicolumn{9}{|l|}{ Education } \\
\hline Bachelor & 154 & 75.1 & 51 & $24.9 *$ & 76 & 49.4 & 78 & 50.6 \\
\hline Master & 146 & 76.8 & 44 & 23.2 & 69 & 47.3 & 77 & 52.7 \\
\hline $\mathrm{PhD}$ & 14 & 46.7 & 16 & 53.3 & 11 & 78.6 & 3 & 21.4 \\
\hline \multicolumn{9}{|l|}{ Nationality } \\
\hline Middle East & 69 & 71.9 & 27 & 28.1 & 34 & 49.3 & 35 & 50.7 \\
\hline Southeast Asia & 159 & 75.7 & 51 & 24.3 & 78 & 49.1 & 81 & 50.9 \\
\hline Center Asia & 33 & 64.7 & 18 & 35.3 & 19 & 57.6 & 14 & 42.4 \\
\hline North African & 53 & 77.9 & 15 & 22.1 & 25 & 47.2 & 28 & 52.8 \\
\hline \multicolumn{9}{|l|}{ Income } \\
\hline$(\operatorname{mean} \pm \mathrm{SD})$ & \multicolumn{2}{|c|}{$10638.53 \pm 2523.51$} & \multicolumn{2}{|c|}{$10630.63+2101.63$} & \multicolumn{2}{|c|}{$10897.43+2686.11$} & \multicolumn{2}{|c|}{$10382.91 \pm 2332.38$} \\
\hline
\end{tabular}

* $\mathrm{p}<0.002$ for $\mathrm{x}^{2}$-tests

$56(13.2 \%)$, magazine $31(7.3 \%)$, radio $30(7.1 \%)$, fairs $28(6.6 \%)$ and newspaper $22(5.2 \%)$.

Table 2 shows the use of cell phones and interest to receive a cell phone breast cancer prevention messages. Results showed some significant interactions between cell phone use and age confidence $(\mathrm{t}=3.76, \mathrm{p}=0.000)$, nationality $\left(\mathrm{x}^{2}=14.08 ; \mathrm{p}=0.003\right)$ and education $\left(\mathrm{x}^{2}=13.95\right.$; $\mathrm{p}=0.001)$. The prevalence of cell phone use was higher in bachelor degree compared to master and $\mathrm{Ph} . \mathrm{D}$ $(94.4 \%, 87.9 \%$ and $73.3 \%)$ respectively, Middle East compared to Southeast Asia, North African and Center Asia $(94.8 \%, 92.4 \%, 83.8 \%$ and $78.4 \%)$ respectively. Of the cell phone users, significant interactions were found between interest in receiving a cell phone prevention message and nationality $\left(\mathrm{x}^{2}=14.47 ; \mathrm{p}=0.002\right)$. Interests were higher for North African compared to Center Asia, Southeast Asia and Middle East (66.7\%, 62.5\%, 51.0\% and $37.4 \%$ ) respectively. No differences were found between the education, age, income, marital status and cell phone prevention message.

Table 3 shows the use of text messaging, interest in text breast cancer prevention message. A significant interaction was found between education and use text massaging $\left(x^{2}=12.54 ; p=0.002\right)$. Text use was higher for master students compared to bachelor and $\mathrm{Ph} . \mathrm{D}$ students $(76.8 \%, 75.1 \%$ and $46.7 \%)$ respectively. No differences were found between the age, marital status, nationality, income and use of text massaging. Also, no differences were found between independent variables and receiving text breast cancer prevention messages.

\section{Discussion}

The study examined the breast cancer prevention information seeking behaviors among students, the prevalence of Internet, cell, and texting use, and the interest for mobile breast cancer prevention information messages. The findings contribute to the knowledge base 
of breast cancer prevention research by identifying sources of information and technology use among students.

The results indicate the main types of interpersonal sources were traditional sources such as health professionals, friends, and family. These findings are support by Kratzke et al. (2013) that suggested doctor, nurses and family are the main interpersonal sources of information for breast cancer prevention. Another similar study reported that the most important information sources about breast cancer prevention were health professionals (doctors and nurses; 38.3\%), followed by friends (17\%) and printed materials (11\%) (Akhtari-Zavare et al., 2013). This highlights the need to reinforce the important role of health professionals in conversations with patients about breast cancer prevention. However, many students may not visit health professionals for preventive services due to lack of time. They may need to actively seek breast cancer prevention information from other sources if the information is not provided by clinicians.

The three most common channel sources support the use of traditional media such as television, brochure, and the Internet as identified in previous studies (Yilmaz et al., 2013; Yucel et al., 2014; Che et al., 2014). These findings are support by Akhtari-Zavare et al. (2014) that stated television and brochure as the main sources of information for breast cancer and BSE practice among Iranian women in Hamadan, Iran. Another similar studies found that nearly half of the respondents reported their main sources of information on breast cancer and BSE was the media (Gurdal et al., 2012; Redhwan et al., 2011). In contrast, in study done by Kratzke et al. (2014) reported the main source of breast cancer prevention information from the Internet (74.2\%), magazines (68.6\%), television (58.5\%), radio $(43.2 \%)$, and newspapers $(33.6 \%)$.

Internet use is rapidly increasing as a source for breast cancer information and our findings support previous study (Kratzke et al., 2013). The findings showed 13.2\% used the Internet to seek breast cancer prevention information. It is possible the lower utilization may reflect the wording of the item specifically requesting a response for seeking breast cancer information. In two previous studies, Internet use for seeking health information among clinic patients varied from $19 \%$ to $79 \%$ (Noroozi et al., 2009; Dahlui et al., 2011). In other studies, Internet use compared to providers was rated as a more common health information source (Kelly et al., 2009; Walsh-Childers et al., 2011). Cancer survivors are also seeking online information regarding various therapies, treatment, side effects, and disease stages (Sajidet al., 2011; Kirschning et al., 2008).

In the present study, majority of participants $(73.9 \%)$ reported that they used text massaging but only $36.4 \%$ of them prefer text prevention message. These findings are support by Alipour et al. (2012) that reported using the short message service (SMS) via cell phone had a significantly better effect in improving the knowledge about breast cancer and mention as main sources of information on breast cancer. Result of this study showed that there were no differences between sociodemographics and text-message reminder use. This finding was supported in another study of breast cancer survivors (Samal et al., 2009). One possible explanation is that all women using text-message reminder may be familiar with the potential of this mobile messaging capacity. Also, this study reported only education significantly influenced on cell phone message use. It is quite possible that technology crosses educational levels currently compared to the early adoption of cell phone and text messaging use.

Mobile phones have been shown effective in several public health domains (Evans et al., 2012). However, there are few evaluations of the effectiveness of mobile health in health promotion. A recent study showed that young people were more likely to use cell phones to look for health information compared to those in older age groups, suggesting that health-information-seeking patterns are perhaps unique for the Millenial generation (Fox, 2011). Student those using smartphones with wireless Internet also have the potential to access the Internet even though they may not have Internet access at home. Mobile technologies may help close the gap for access to online health information for some students. No significant differences were found between age, income, and marital status among cell phone use. Our finding was supported in other study (Kratzke et al., 2014). Pew Internet research suggests the use of mobile technology will continue to grow and more people in different age groups will be using cell phones (Brenner, 2012).

There are some limitations in our research. Firstly, this study was designed as a cross-sectional survey and did not include monitoring of the participants. Secondly, data were collected by self-reporting and this might be affected by memory bias.

In conclusion, the findings have important implications for health educators and health professionals working with young women and developing breast cancer prevention information. The findings confirm traditional sources will continue to be used by women seeking breast cancer prevention information..

\section{Acknowledgements}

Researchers would like to thank all the students who took part in the study and gratefully acknowledge the management officer and staff of post graduate center of selected University that involved in this study.

\section{References}

Akhtari-Zavare M, Ghanbari-Baghestan A, Latiffah AL, et al (2014). Knowledge of breast cancer and breast selfexamination practice among iranian women in hamadan, Iran. Asian Pac J Cancer Prev, 15, 6531-4.

Akhtari-Zavare M, Muhamad HJ, Salmiah MS, Irmi AM (2013). Beliefs and behavior of Malaysia undergraduate female students in a public university toward breast selfexamination practice. Asian Pac J Cancer Prev, 14, 57-61.

Alipour S, Moini A, Jafari-Adli SH, Gharaie N, Mansouri KH (2012). Comparison of teaching about breast cancer via mobile or traditional learning methods in gynecology residents. Asian Pac J Cancer Prev, 13, 4593-5.

American Cancer Society (2013). Cancer facts and figures 2013. Atlanta: American Cancer Society.

Andsoy I, Gul A (2014). Breast, cervix and colorectal cancer knowledge among nurses in Turkey. Asian Pac J Cancer 
Prev, 15, 2267-72.

Brenner J (2012). Pew internet: Mobile. Pew internet \& American life project [Online], Available:http://www. pewinternet.org/Commentary/2012/February/Pew-Internet Mobile.aspx. [2013, May 21].

Che CC, Coomarasamy JD, Suppayah B (2014). Perception of breast health amongst Malaysian female adolescents. Asian Pac J Cancer Prev, 15, 7175-80.

Dahlui M, Ng CW, Al Sadat N, Ismail S, Bulgiba AM (2011). Is breast self examination (BSE) still relevant? a study on BSE performance among female staff of University of Malaya. Asian Pac J Cancer Prev, 12, 369-372.

Early J, Armstrong SN, Burke S, Thompson DL (2011). U.S. female college students' breast health knowledge, attitudes, and determinants of screening practices: New implications for health education. J Am Coll Health, 59, 640-7.

Evans WD, Abroms LC, Poropatich R, et al (2012). Mobile Health Evaluation Methods: The Text4baby Case Study. $J$ Health Commun, 17, 22-29.

Fox, S (2011). Profiles of health information seekers. Retrieved from Health Topics [Online], Available: http://www. pewinternet.org/Reports/2011/HealthTopics/Part-2/Intro. aspx. [2014, March 20].

Fukuoka Y, Komatsu J, Suarez L, et al (2011). The mPED randomized controlled clinical trial: Applying mobile persuasive technologies to increase physical activity in sedentary women protocol. BMS Public Health, 11, 933.

Ghanbari-Baghestan A, Akhtari-Zavareh A, Abu Hassan A (2009). Communication channels used by academic staff in interacting with their students. Pertanika J Soc Sci Hum, 17, 167-78.

Gurdal SO, Saracoglu GV, Oran ES, et al (2012). The effects of educational level on breast cancer awareness: a crosssectional study in Turkey. Asian Pac J Cancer Prev, 12, 295-300

Kelly K, Sturm A, Kemp K, Holland J, Ferketich A (2009). How can we reach them? Information seeking and preferences for a cancer family history campaign in underserved communities. J Health Communication, 14, 573-89.

Khaniki H, Rassi-Tehrani H (2011). The study of audience's point of view about health messages on TV. J CultureCommunication Studies, 12, Series 47.

Kirschning S, Kardorff E (2008). The use of the Internet by women with breast cancer and men with prostate cancer: Results of online research. J Public Health, 16, 133-43.

Kratzke C, Amatya A, Vilchis H (2014). Differences among college women for breast cancer prevention acquired information-seeking, desired apps and texts, and daughterinitiated information to mothers. J Community Health, $\mathbf{3 9}$, 291-300.

Kratzke C, Wilson S, Vilchis H (2013). Reaching rural women: breast cancer prevention information seeking behaviors and interest in internet, cell phone, and text use. J Community Health, 38, 54-61.

Longo D, Ge B, Radina M, et al (2009). Understanding breastcancer patients' perceptions: Health information seeking behavior and passive information receipt. J Communication in Healthcare, 2, 184-202.

Motlik S (2008). Mobile learning in developing nations. Int Rev Res Open Distance Learning, 9, 1-7.

Noroozi A, Jomand T, Tahmasebi R (2011). Determinants of breast self-examination performance among Iranian women: an application of the health belief model. J Canc Educ, 26, $365-74$.

Pew Internet and American Life Project (2013). Health Online 2013[Online], Available: http://www.pewinternet.org/ Reports/2013/Healthonline.aspx. [2013, July 14].
Pew Internet and American Life Project (2012). Cell phone activities 2012[Online], Available: http://pewinternet. org/ Reports/2012/Cell-Activities aspx.[2013, July 20].

Redhwan AA, Dhekra HA, Yuri V BB, et al (2011). Practice and barriers toward breast self-examination among young Malaysian women. Asian Pac J Cancer Prev, 12, 1173-8.

Rice RE, Katz JE (2003). Comparing internet and mobile phone usage: Digital divides of usage, adoption, and dropouts. Telecommun Policy, 27, 597-623.

Sajid J, Shakir A, Baig M (2011). Information on the internet about colorectal cancer: Patient attitude and potential toward Web browsing. A prospective observational study. Can J Surg, 54, 339-43.

Samal L, Hutton H, Erbelding E, et al (2009). Digital divide: Variation in internet and cellular phone use among women attending an urban sexually transmitted infections clinic. $J$ Urban Health, 87, 122-8.

Walsh-Childers K, Edwards H, Grobmyer S (2011). Covering women's greatest health fear: Breast cancer information in consumer magazines. Health Communication, 26, 209-220.

World Health Organization (2009). Breast cancer: prevention and control [Online], Available: http://www.who.int/cancer/ detection/breastcancer/en/index3.html [2012, March 13].

Yilmaz D, Bebis H, Ortabag T (2013). Determining the awareness of and compliance with breast cancer screening among Turkish residential women. Asian Pac J Cancer Prev, 14, 3281-8.

Yip CH, Cazap E, Anderson BO, et al (2011). Breast cancer management in middle-resource countries (MRCs): consensus statement from the breast health global initiative. Breast, 20, 129.

Yucel SC, Orgun F, Tokem Y, et al (2014). Determining the factors that affect breast cancer and self breast examination beliefs of Turkish nurses in academia. Asian Pac J Cancer Prev, 15, 1275-80. 